\title{
Possibilities of Applying the Thematic Contents of Environmental Education in Ethical Education in Slovakia
}

\author{
Możliwości zastosowania edukacji ekologicznej w edukacji etycznej na Słowacji
}

\author{
Barbora Bad'urová \\ Faculty of Education, Matej Bel University in Banská Bystrica, Slovakia \\ ORCID: https://orcid.org/0000-0002-3805-9038•barbora.badurova@umb.sk \\ Received: 23 Aug 2020; Revised: 06 Oct 2020; Accepted: 09 Oct 2020
}

\begin{abstract}
The text deals with the possibilities of the utilisation of cross-curricular themed Environmental education in the school subject, "Ethical Education" in Slovakia, especially in lower secondary education. The text partly stems from work on the project APVV-14-0176 "Didactic Means Facilitating the Implementation of Selected Cross-Curricular Topics in the Teaching of Ethical Education at the Second Level of Primary School", and offers a brief overview on how the topics of ethical education may overlap with environmental education. To achieve this goal, the first part of the text briefly characterises ethical education in Slovakia, and introduces its key figures and principles, as well as the elements of environmental education in ethical education, and a brief summary of the content of the cross-curricular topic, "Environmental Education in the Current National Curriculum" follow. The suggestions for implementation of environmental education in ethical education in Slovakia, form the last part of the paper, where the author also describes some problem areas of the subjects. The author concludes that it is also possible to apply environmental themes in current ethical education; however, it requires some creativity, critical thinking, suitable teaching materials, and competent, dedicated teachers.
\end{abstract}

Keywords: ethical education, environmental education, Slovakia

Streszczenie: Opracowanie to dotyczy możliwości wykorzystania międzyprzedmiotowej tematyki edukacji ekologicznej w ramach przedmiotu szkolnego edukacji etycznej, zwłaszcza w szkołach średnich I stopnia na Słowacji. Opracowanie odwołuje się do projektu APVV-14-0176 i zawiera krótki przegląd tego, jak tematy edukacji etycznej mogą pokrywać się z edukacją ekologiczną. Aby osiągnąć ten cel, w pierwszej części artykułu krótko scharakteryzowano edukację etyczną na Słowacji i przedstawiono jej istotne elementy. Następnie przedstawiono elementy edukacji ekologicznej w ramach edukacji etycznej oraz krótkie podsumowanie treści tematyki międzyprzedmiotowej edukacji ekologicznej w aktualnym programie nauczania. Propozycje wprowadzenia edukacji ekologicznej do edukacji etycznej na Słowacji stanowią ostatnią część artykułu, w której autorka opisuje niektóre problematyczne obszary tematyczne. Autorka konkluduje, że wątki środowiskowe można zastosować także w obecnej edukacji etycznej, jednak wymaga to kreatywności, krytycznego myślenia, odpowiednich materiałów dydaktycznych i kompetentnych, oddanych nauczycieli.

Słowa kluczowe: edukacja etyczna, edukacja środowiskowa, Słowacja 


\section{Introduction}

According to the report on the state of the environment (Lieskovská et al. 2017) published by the Ministry of Environment of the Slovak Republic, the environment still suffers from many problems. Several environmental risks may be perceived also on the global level. Due to the fact that environmental problems are often very complex and interdisciplinary (or transdiciplinary) solutions are required. One solution includes improving education in this area ${ }^{1}$. The paper offers several ideas how the topics of the current model of Slovak Ethical education may overlap with Environmental education. To achieve this goal, the first part of the article shortly characterises Ethical education in Slovakia and introduces its key figures and principles, followed by an outline of the elements of environmental education in Ethical education and a brief summary of the content of the cross-curricular topic of Environmental education in the current national curriculum. The suggestions for implementing Environmental education into Ethical education in Slovakia form the last part of the paper where the author describes also some problem areas of the subjects. The author concludes that it is possible to apply environmental themes also in the current Ethical education, however, it requires some creativity, critical thinking, suitable teaching materials and competent dedicated teachers.

1 In this regards it is possible to mention The United Nations Decade of Education for Sustainable Development (2005-2014) which is also oriented on interdisciplinary solution of environmental damage and aimed to promote more sustainable future also via proper education (UNESCO 2014). Similarly, it is stated by EU Sustainable Development Strategy (Communication from the Commission A Sustainable Europe for a Better World: A European Union Strategy for Sustainable Development): “The education system also has a vital role to play in promoting better understanding of the aim of sustainable development, fostering a sense of individual and collective responsibility, and thereby encouraging changes in behaviour." (EULex 2001).

\section{Ethical education in Slovakia: a short characteristic}

Ethical education is conceived as a compulsory elective subject that is taught in primary and secondary education from the period of 1990 s. This subject is an alternative to confessional Religious education and is not graded. The subject is based primarily on the concept of education for prosociality of a Spanish psychologist, Roberto Roche Olivar which was disseminated in Slovakia by a pedagogue, Ladislav Lencz (1992).

One of the key texts of R. R. Olivar is a book entitled Psichologia y Education de la Prosocialidad originally published in 1990. This text was edited in Slovakia under the title Etická výchova - that is Ethical education in 1992 and the book was recommended by the Slovak Ministry of Education as a textbook for Ethical education for primary and secondary education. The author of the introduction, the above mentioned Ladislav Lencz, later in 1993 published related books focused on Ethical education entitled Pedagogika etickej výchovy: Výchova $k$ prosociálnosti (Pedagogics of Ethical Education: Education to Prosociality) (Lencz 1993a) and Metódy etickej výchovy (Methods of Ethical Education) (Lencz1993b). These books are primarily oriented on pedagogy of Ethical education with elements of humanistic psychology (Bad'urová 2016).

Despite the fact that Ethical education started to form in the early 1990s, the current concept of Ethical education in Slovakia are still significantly influenced by the theories of prosociality of Roberto Roche Olivar and Ladislav Lencz, especially due to the paucity of other teaching materials (Poláková 2016; Poláková and Bad’urová 2015). To get a more complete picture, we may look at the subject from the point of view of current national curriculum. The national curriculum which is named the Innovated State Educational Program for lower secondary education (2015) mentions that the main task of this subject is to actively participate in forming the personality of students with their own identity and value orientation, an important 
place in this area takes respect for human and nature, cooperation, prosociality and universal human values. The State Educational Program claims that in meeting that objective, this educational area should not focus only to providing information on moral principles, but should particularly encourage understanding and internalisation of moral standards and the adoption of behavior that is consistent with them. The role of Ethical Education as a compulsory optional course is to educate and develop personality with his/her own identity and value orientation and promote prosociality (SEP 2015). The main topics in the lower secondary education (age 10-15) include: (SEP 2015)

$5^{\text {th }}$ grade: Open communication, Knowledge and positive assessment of oneself, Knowledge and positive assessment of others, Creativity in the interpersonal relations,

Ethical aspects of nature protection.

$6^{\text {th }}$ grade: Identification and expression of emotions,

Cognitive and emotional empathy,

Assertive behaviour,

Positive role-models in the

history and literature,

Positive role-models in

everyday life,

Prosocial behaviour.

$7^{\text {th }}$ grade: Discovering own identity and individuality,

Being oneself, being able to defend own rights and opinions,

Prosociality as a component of own identity,

Ethical aspects of relationship to own family, Ethical aspects of integration of sexual maturity into the context of personality,
Relation to the sick, elderly, physically and socially disadvantaged.

$8^{\text {th }}$ grade: Sources of ethical knowledge of mankind, Life, physical and mental health ethical value, Economical values and ethics, Good reputation and truth as ethical values.

$9^{\text {th }}$ grade: Enhancing communication skills, Healthy lifestyle, Addictions, Mass media influences.

These topics are included in the national curriculum shortly clarified in terms of content and performance standards, however, as it is only a very brief description (usually 5-6 lines on each topic) it leaves much room for the schools and creativity of teachers how to implement them.

\section{Environmental education in Slovak Ethical education}

Although Ethical education in Slovakia on the primary and secondary level of education is based on the concept of prosociality, especially towards other members of society, it includes also some elements of environmental education. To be more precise, the issue of nature conservation is explicitly located at the lower secondary education, however, only in the fifth grade. The focus is on the Ethical Aspects of Nature Protection (which, in the older State Education Program (2009), was called Nature and Environment Protection.) In the Innovated State Education Program (2015), which is now being introduced into all levels of education, are the objectives and standards expressed more concisely. Thus, the general objectives fail to provide a more specific description of the thematic unit Ethical Aspects of Nature Conservation in more detail. Such issues as the goal of nature conservation, or respect for nonhuman forms of life, or the cultivation of other ecological values, are not found. 
The performance standard of the topic is to justify personal responsibility for environment of every human, be able to write an essay about the relation towards the nature, create a project of nature protection in local environment as well as perform concrete activities focused on the nature protection. The content standard is focused on ecosystems, perception of nature, relation between human activity and the environment, responsibility for nature (SEP 2015). As we may observe, unfortunately these very briefly defined goals do not concretely specify ethical aspects of environmental issues. However, this leaves room for creative approach to the topics by the teacher.

\section{The cross-curricular topic of Environmental education}

Environmental ethical education seems to be insufficient if it is taught only as one of the 5 topics in the $5^{\text {th }}$ grade. Fortunately, there is a possibility of introducing the so called cross-curricular subject focused especially on Environmental education. Environmental education is sometimes referred to as ecological education, ecoeducation, eco-pedagogy ${ }^{2}$ and it often combines not only knowledge of natural sciences such as ecology but also social sciences such as ethics, axiology, psychology, pedagogy or sociology. It is also clear from this characteristics that environmental ethics must work closely with ethics as it should not only exploit the knowledge of natural sciences such as ecology but also knowledge from the field of axiology, such as teaching about values and ethics, or philosophy of morality.

In Slovakia, Environmental education is implemented as a cross-curricular topic and several teaching subjects are to be used in its implementation. The cross-curricular theme Environmental education is one of six crosscurricular themes. In the educational areas

2 Description of different approaches to environmental education can be found e.g. in Kopnina (2014).
Human and Nature, Human and Society, Human and World of Work, The Health and Movement, the emphasis is placed on the understanding of natural and social laws and, in this respect, it is possible to apply Environmental education also into them. Environmental education can also be applied in connection with some other crosscurricular themes for instance Protection of Life and Health. However, for the purpose of this paper the most interesting seems to be integration of environmental education into the area of Human and Values, which emphasizes moral relationships, moral standards and values and includes besides various forms of Religious education also the subject Ethical education (SEP 2015; Bad'urová and Kaliský 2016).

According to the characteristics of a given cross-curricular theme, Environmental education "leads pupils to a comprehensive understanding of the interrelationships between organisms and the relationship of human to the environment" (Kelcová 2009, 2), with an emphasis on understanding the necessity of transition to sustainable development of society. The benefits of this cross-curricular theme are two-tier, in terms of knowledge, skills and capabilities, focusing primarily on understanding, analyzing and evaluating human relationships and their environment (human, local and global issues, consumer and producer responsibilities). On the other hand, it also focuses on attitudes and values and the objectives are oriented towards perceiving life as the highest value, enhancing the sense of responsibility in relation to living organisms and their environment in the context of active creation and protection of the environment as well as to its aesthetic value and healthy lifestyle. It follows that Environmental education is perceived as a suitable means of influencing environmental assessment, pupils' feelings and behaviour, it includes areas of perception, knowledge, that is, rational grasp, moral evaluation, but also action, that is, practical activity (Kelcova 2009; Bad’urová and Kaliský 2016). 
Environmental education, which was approved by the State Pedagogical Institute in 2009, includes five thematic areas: nature and landscape conservation (forests, fields, water resources, sea, tropical rainforest, human settlements, urbanization); components of the environment (water, air, soil, biodiversity conservation); natural resources, their use and protection (meaning for human, renewable and non-renewable natural resources, rational use in relation to sustainable development, alternative energy sources); human activities and environmental issues (impacts of agriculture, transport, industry, waste management, nature and cultural heritage protection, urbanization impact, long-term political programs and legislative concepts); the relationship of man to the environment (our community, lifestyle and consumerism, local and global environmental problems, quality of life and environmental health) (Kelcová 2009, 4-5).

The cross-curricular theme of Environmental education under the Innovated State Education Program (2015) enables students to acquire knowledge, skills, attitudes and habits to protect and improve the (natural) environment that they understand to be important for a sustainable life on Earth. This cross-curricular theme should lead pupils to a comprehensive understanding of the relationships between humans, organisms and the environment, where ecological, economic and social interrelationships are highlighted, though it may well be highlighted morally. The aim of this cross-curricular theme is to ensure that pupils respect the basic rules of behaviour in nature with regard to (or look at) other organisms and their environment, recognize and evaluate changes in nature and in their surroundings. Apart from that, they should know the possibilities of protecting and improving the environment, actively participate in activities (of schools) aimed at protecting and improving the environment of the wider surroundings (schools, municipalities...), they should acquire information on human interventions in the environment and be able to evaluate their implications in local and global contexts, they should also be able to distinguish between environmentally friendly technologies and products, and to act responsibly towards natural resources and actively participate in the elimination of environmental pollution (SEP 2015).

We can sum up that Environmental education in Slovakia should ideally develop not just the cognitive level of understanding environmental issues but also their affective and conative dimension ${ }^{3}$. Education should just focus on knowledge but also on attitudes, therefore there is a room for Ethical education and for approaching problems from the point of view of ethics.

\section{The possibilities of applying the cross- curricular topic in Ethical education}

Explaining in terms of the popular revised Bloom's taxonomy (Anderson and Krathwohl 2001), we can summarize that by applying the cross-curricular theme of Environmental education into Ethical education we may develop:

- knowledge - pupils can identify ecological problems of the present, identify possibilities for protection and improvement of the environment, gain information about human interventions in the environment, get familiar with the basic ideas of environmental ethics and the basic pillars of their approaches;

- $\quad$ understanding - pupils understand the link between human activity, values and impacts on nature, ecosystems, know and can assess changes in nature and its surroundings;

- aptitude - pupils can apply approaches of environmental ethics to concrete examples from practice, participate in activities (of schools) aimed at protecting and improving the environment of the wider environment (schools, municipalities ...);

3 To the conative dimension see e.g. Goralnik, Nelson (2011). 
- analytical ability - pupils can analyse environmental issues - globally and locally from the ethical point of view, can distinguish environmentally friendly technologies and products;

- ability of synthesis - pupils can create a classification of causes of ecological problems and possible solutions from the point of view of environmental ethics;

- $\quad$ assessment ability - pupils are able to argue and take a stance on ecological problems, to conduct actors who contribute, for example, to environmental pollution, are aware of what values are in conflict when solving moral dilemmas;

- creativity - pupils are able to create a project to solve local ecological problems and actively participate in the elimination of environmental pollution, etc. (Bad'urová and Kaliský 2016). In order to achieve educational goals, it is also possible to describe it in terms of wellknown Kolb's model of experiential learning (Kolb 1983), which is realized in four steps: experience - reflection - theoretical conceptualization - experimentation.

1. Experience - specific planned or accidental experience (the pupil pursues an activity): a trip to a natural place, an excursion to an animal shelter, a waste recycling company, a trip to an environment where a landfill, protected landscape area,

2. Reflection - a retrospective view of the experience, reflections on what happened, an active reflection on the experience, its meaning (the participant observes, describes): a description of what we have seen, what is good, the work of shelters; discussion on related environmental issues, reflection on ethics: Why is the environmental problem also a problem in terms of ethics?; questions of environmental values, reflection in terms of responsibility: Who is responsible for the situation?
3. Theoretical conceptualization - identification of principles, systematization of knowledge into the system and context, generalization, search for causes, emergence of different theories and ideas - search for reasons, for example, why there are many animals in shelters, how could the problems be solved, how do we shape our attitude to pets.

4. Experimenting - verifying the acquired knowledge and new skills in new situations, actively experimenting (the learner acts, experiences other situations, answers the question "What is next?") - creating a project to improve the situation in its surroundings and project it into practice - waste screening campaign, creation of new made from old, campaign to promote responsible animal care, etc. (Badurová and Kaliský 2016).

Ethical education has a great potential for the development of active nature protection and respect for life, as its key objectives include the development of prosocial action. This can also be developed in the interests of non-anthropocentric concepts in relation to non-human natural beings, for example, in the form of different kinds of aid to animals as well. The second key goal of Ethical education is the development of empathy, which is best reached by an immediate experience and reflection in the educational process. Therefore, it is appropriate for Environmental education to be implemented in particular through experiential forms of learning.

Despite the fact that the topic focused on environmental ethics and education is explicitly mentioned only in the $5^{\text {th }}$ grade we can see the link between environmental issues and all the topics of Ethical education. For instance, we may connect the themes as follows: Topic Open communication and assertiveness (5th grade) may be easily linked to environmental education since appropriate communication skills and especially assertive communication (similarly also the 
theme of Assertive behavior, 6th grade) is also suitable for conducting discussions on environmental problems and conflicts when it is necessary to seek consensus of different interests groups (for example, in discussions on the cultivation of genetically modified crops). In the topic To be oneself and to be able to defend one's own rights and opinions (7th grade), which is the development of the themes mentioned above and contributes to the development of the ability to argue and lead a discussion on environmental issues. Similarly, it can be connected to the topic Deepening communication skills in the 9 th grade. The theme Knowledge and positive assessment of oneself and others, (5th grade) is related to the environmental issue too. For example, it is possible to point out that the issue of environmental injustice is linked to denial of human dignity. Also, for instance, helping to tackle environmental injustice can be a form of prosocial behaviour, that is to say, related to Prosocial behaviour (6th grade) and Prosociality as a component of one's own identity (7th grade). It is similarly related to the issue of the Relationship to sick, old, health and socially disadvantaged people (7th grade), since environmental injustice is often hand-in-hand with other forms of injustice, also linked, for example, to social exclusion. Promoting ability to solve environmental problems is also related to the theme Creativity in interpersonal relationships, (5th grade), since solutions (of all but not only) environmental projects require adequate creativity, innovation and initiative. Cognitive and emotional empathy, (6th grade), as one of the most important topics of ethical education, is equally applicable not only towards other people but to animals as well. This is followed by the topic Identification and expression of emotions (5th grade), which can also be oriented towards the relationship to nature and expression of the emotional relation to it. The themes Positive role-models in everyday life and Positive role-models in history and literature (5th grade) can also be done in cooperation with some environmental activists or ethicists, or it may be connected for example to introduction of ideas of A. Schweitzer or many others. The theme Ethics and economic values (8th grade) is related to the issue of consumption and population growth that lead to environmental devastation. The theme Sources of ethical knowledge of mankind (8th grade) can point to approaches to nature in different world religions. In this context, it can be said that, for example, L. White blamed Christianity for the ecological crisis, even though Francis of Assisi as an animal protector or A. Schweitzer as a representative of the environmental concept of respect for life ethics were Christians, which can serve as an interesting theme for discussion. Similarly, it is possible to point out that some adherents of deep ecology turn to mystics and eastern religions and seek connection with nature. The topic focused on the family The ethical aspects of the relationship in my own family (7th grade) is also related to the environmental issues, for example, domestic animals are often considered to be part of our family. We may also discuss different approaches to gender roles (see e.g. Blenkinsop, Piersol, De Danann Sitka-Sage, 2018). Similarly, the theme focused on education for marriage and parenthood or the Ethical aspects of the integration of sexual maturity in the context of personality (7th grade) builds on the issue of population growth, which is one of the ecological problems of the present and creates scope for discussion on responsible parenthood. The topic The influence of mass media in the 9th year is applicable for instance in connection with the development of critical viewer in relation to reports on environmental problems, disasters in different parts of the world, and space for a cultivated exchange of views on the balance and credibility of this information (Bad'urová 2015; Badurová and Kaliský 2016; Bad’urová 2017b).

As we have seen with some creativity on the part of teacher, it is possible to apply environmental ethics and education to most of the themes of Ethical education. Suitable implementation, however, requires also that teachers are familiar not just with 
psychological and pedagogical aspects of education but also with environmental philosophy.

\section{Some problem areas for further discussion}

Despite the fact that the Slovak model of Ethical education based on the concept of prosociality has several advantages as for instance developing better relations between pupils and teachers (Lencz 1992; 1993), there are also several problem areas (Bad'urová 2015). I classified them into four dimensions: the problem of status of the subject; the problem of relationship to akin subjects and cross-curricular themes; the problem of qualification of teachers; and the problem of content of the subject. The first problem is that the subject is often perceived as not so important also due to the fact that it is not graded. The second problem is related, for instance, to searching suitable relation to Religious education. The problem of teachers' qualifications stems from the fact that Ethical education does not comprise a big number of teaching hours and therefore it is often taught by teachers who need to fill their work time but are not specialised in this area. The problem of the content is also related to the topic of this article but is also connected to the issue that there is not suitable philosophical and ethical basis of the subject especially in terms of metaethics, but also there is not much room for normative ethics and practical ethics.

Ethics education can be developed with the emphasis on psychology, pedagogy or philosophy. Various curricula usually manifest greater importance of one of these approaches. I think that all of these approaches are important but I will put emphasis on the philosophical aspects of ethical education, because I assume that this area is important for the development of an individual who is able to stay healthy, be critical and use his/her own practical reason, in other words, who is able to think critically, understand which information is biased, which is on the other hand relevant, and who is able to decide what decision would be the best in a given situation. From my point of view, Ethical education should not be just a form of moral training that uses psychological and pedagogical tools without sufficient philosophical basis. I assume that it is important to implement elements of ethics as practical philosophy into ethical education, too. Although this does not mean that psychological and pedagogical procession of the subject is not important, because these approaches can help educators achieve goals set by ethical education. However, philosophy and ethics should be the very basis of the information in the curriculum (Badurová 2017b).

As the topic of this paper is the relation between Ethical education and Environmental education, I will also look at some problems of current Environmental education in Slovakia. The current form of Environmental education has been criticised, for example, by S. Milová, R. Medal, J. Klocoková (2012) ${ }^{4}$ who believe that modern environmental education and training in practice should be primarily interdisciplinary and broadly conceived, as well as focused on context, transcendence, relations, at the same time reflecting the development of the world and of human society as well as topics of value behaviour, including philosophical and spiritual, civic and social, ethical and moral, social issues. They think that Environmental education should be understood primarily as education having an ethical and social dimension.

In analysing the positive aspects of the contemporary Environmental education in Slovakia as a cross-curricular theme, it is possible to mention the following: there is

4 Although this is a rather old text, it seems that the situation did not evolve a lot since the model of cross-curricular topic, despite the innovation of national curriculum. There also very few projects addressing a given issue. Moreover, there is still lack of suitable teaching materials especially oriented not just on the point of view of natural sciences but also on humanities. 
freedom of choice for teachers and schools, for educational programs, the possibility of plurality of teaching models, provides the possibility of linking formal education with environmental education with informal and using the offer of environmental programs of non-governmental organizations in formal education, focusing on the whole population of children (great educational potential), leading to easier organization of teaching for schools, saving of funds.

On the other hand, the negative aspects of the contemporary Slovak Environmental education are, for example formalism, superficiality, also that the implementation of quality environmental education is time-consuming and preparatory, the consequence is that children often receive only separate information, escaping the connections and being passive, the problem is also the rivalry of environmental education with other cross-curricular themes, similar to the fact that the quality of environmental education also depends on the teacher's access, motivation or managerial skills, the problem is also the lack of qualified educators or moral authorities (Milová, Medal and Klocoková 2012). Similarly, also problematic is the education of teachers. It is often unsystematic, the lecturers and content of the training courses is not always appropriate, not coordinated and accredited nationwide, represented in all regions. Education in this area is left many times only to the interest of teachers themselves, and teachers are not sufficiently motivated to supplement their education in this area (Milová, Medal, and Klocoková 2012). Klocoková (2014) based on her study observed that teachers suggest building more ecological centres for environmental education where the education can be realised.

Moreover another problem of environmental and ethical education is that often in the curriculum (Kelcová 2009; SEP 2015), unnecessarily large space is dedicated to activities devoted to the contemplation of the beauty of nature although it can lead students to the conclusion that nature and its components are worthy of interest and protection only when they are beautiful. Many people feel resistance to animals, such as bats, and consider them unattractive, despite being for some other more important reasons worthy of protection. In this context, in Ethical education, emphasis should also be put on moral reasoning on issues relating to the anthropocentric and non-anthropocentric concepts and the resulting relationship of value attitudes towards non-human natural entities.

We may agree with S. Milová, R. Medal, and J. Klocoková (2012), who based on their research, state that in Slovakia it is necessary to elaborate strategy and goals of school ecoeducation, i.e. goals for the sustainability of school facilities. This would motivate schools to use modern forms of environmental education. It would also encourage schools to build co-operation between schools and between pupils, educators and various environmental NGOs and activists. It is the non-governmental organizations that play an important role in environmental education and training, so it is important to support their activities. I agree with those authors who believe that it is also necessary to address the environmental issues more fully at the level of society as a whole, and to open a whole-hearted discussion on this topic. It is therefore important to organize regular conferences or forums to discuss the roles, goals and practical experiences of environmental education between domestic and foreign experts, educators, activists and representatives of relevant organizations. It is important to educate children and young people about sustainability in order to promote their active participation in various environmental projects. It is equally important to reflect on the effectiveness of Environmental education in Slovakia through representative research ${ }^{5}$.

5 The state of environmental education in Slovakia was partly described also some years ago in the proceedings by Fedor and Pavličková (2013). 


\section{Conclusion}

I believe that despite the fact that the subject Ethical education in Slovakia is explicitly oriented on the moral dimension of nature conservation and environmental issues only in one thematic area, it is possible (as well as desirable) to integrate environmental issues into all its topics. As we have seen above, it is clear that the cross-curricular theme of Environmental education is closely related to Ethical education, not just due to the fact that Ethical education includes a topic focused on the ethical aspects of nature conservation but all of the topics can be enriched of environmental dimension. However, unfortunately, in many documents Ethical education is likely to reduce the issue of environmental education and environmental ethics only to the so-called anthropocentric approach (at the expense of non-anthropocentric ethical approaches) as it understands only human as the highest value. In the innovated State Education Program, it is literally stated that the goal is to empower pupils to respect "the highest value, which is the life of human and all that leads to his development." (SEP 2015, 3). However, it is important to point out that in Environmental education, which should also be based on environmental ethics, there are also other so-called non-anthropocentric approaches that do not perceive as the highest value only the life of humans but also of other natural beings whose value is not derived solely from human needs. At least due to the development of critical thinking, it would also be worthwhile to point to such alternative approaches. I also believe that the emphasis on the life of humans does not match the benefits of environmental education, according to Kelcová (2009) the goal of attitudes and values is to begin to perceive life (in general) as the highest value.

I assume that Ethical education should be enriched by the project learning, which teaches collaboration, critical thinking, responsibility and focus on the problem. Pupils in groups can work together to solve a local environmental problem such as illegal landfill, sanitation for waste sorting, animal care, and so on. In ethical education classes, it is possible to enrich the debate on issues of environmental ethics (such as different approaches to environmental ethics - anthropocentrism, biocentrism, ecocentrism, pathocentrism, animal ethics, etc.). Consequently, it is also useful to exercise activities as providing a solution to real or fictitious moral dilemmas related to environmental problems, which lead to improving the ability of analysis, communication, argumentation and critical thinking of pupils.

The importance of ethics in environmental education has been similarly pointed out by e.g. Poole et al. (2013), however, in the American context. I agree that the presentation of environmental issues merely in a scientific and value-free way is problematic. In educational process, presentation of value free facts is soften not really achieved, moreover, when teachers and students consciously fail to focus their attention on the ethical dimension of environmental issues they can present ethical aspects without critical philosophical understanding of them, weighting arguments and so on.

The problems of relation between Ethical education and Environmental education has been addressed also by the project APVV14-0176 "Didactic means facilitating the implementation of selected cross-curricular topics in the teaching of ethical education at the second level of the primary school." This project was focused partly on the possibilities of implementing the cross-curricular themes into Ethical education. Based on the research leading to the conclusion that teachers lack suitable teaching materials, we created several textbooks and organised several successful workshops oriented, among others, on the possibilities of implementing Environmental education into Ethical education $^{6}$. I am therefore convinced that it is

6 The project solved pedagogically very current issue - the one of supplying didactic materials 
possible to apply environmental themes also in the current Ethical education, however, it requires some creativity, critical thinking, suitable teaching materials and competent dedicated teachers. This approach has a great potential for raising not just the awareness but also the motivation to act in an environmentally friendly way.

Acknowledgement: I am very grateful for the helpful comments from anonymous reviewers which helped to improve my article.

\section{Bibliography}

Anderson, Lorin W., and Davik R. Krathwohl (eds.). 2001. A taxonomy for learning, teaching, and assessing: A revision of Bloom's taxonomy of educational objectives. New York: Longman.

Bad'urová, Barbora, and Jan Kaliský. 2016. "Environmentálna výchova ako prierezová téma v etickej." In Prierezové témy v etickej výchove, edited by Štefan Ligas, and Eva Poláková, 138-168. Banská Bystrica: Belianum.

Badurová, Barbora. 2015. Environmentálna etika a výchova. Banská Bystrica: Belianum.

Bad’urová, Barbora. 2016. "Selected Problems of Current Ethical Education in Slovakia." Educazione: giornale di pedagogia critica 5(2): 67-92.

Badurová, Barbora. 2017a. Environmentálna výchova žiakov v predmete etická výchova: multimediálny didaktický materiál pre učitelov základnej školy. Banská Bystrica: Belianum.

necessary for effective teaching of cross-curricular themes at elementary schools. Based on the analysis of theoretical sources and own research, teaching materials were created for cross-curricular themes - media education, multicultural education, environmental education and personal and social development in the subject Ethical education at the lower secondary education. Publications are available also for instance on the website of the Department of Ethical and Civic Education, Faculty of Education, Matej Bel University. Dissemination of the results of the project related to school practice was also realized in workshops / didactic courses for teachers to acquire skills in the use of these materials directly in education.
Badurová, Barbora. 2017b. "Ethical education in Slovakia from a Philosophical Point of View.“ Europa Forum Philosophie 66: 104-114.

Blenkinsop, Stephen, Laura Piersol, and Michael De Danann Sitka-Sage. 2018. "Boys being boys: Eco-Double consciousness, splash violence, and environmental education." The Journal of Environmental Education, 49(4): 350-356.

EUR-Lex. 2001. "Communication from the Commission A Sustainable Europe for a Better World: A European Union Strategy for Sustainable Development." Accessed October 15, 2020. https://eur-lex.europa.eu/legal-content/EN/ TXT/?uri=CELEX:52001DC0264.

Fedor, Peter, and Katarína Pavličková (eds.). 2013. Stav a perspektívy environmentálneho vzdelávania. Bratislava: Univerzita Komenského.

Goralnik, Lissy, and Michael P. Nelson. 2011. "Framing a Philosophy of Environmental Action: Aldo Leopold, John Muir, and the Importance of Community." The Journal of Environmental Education 42(3): 181-192.

Kelcová, Mária. 2009. Environmentálna výchova. Accessed September 22, 2017. http://www. statpedu.sk/sk/Statny-vzdelavaci-program/ Statny-vzdelavaci-program-pre-2-stupenzakladnych-skol-ISCED-2/Prierezove-temy/ Environmentalna-vychova.alej.

Klocoková, Jana. 2014. “Environmentálna výchova ako otvorený projekt vytvárania významov a praktík starostlivosti o svet." Sociológia 46(5): 504-533.

Kolb, David A. 1983. Experiential Learning: Experience as the Source of Learning and Development. New York: Prentice Hall.

Kopnina, Helena. 2014. "Future Scenarios and Environmental Education." The Journal of Environmental Education 45(4): 217-231.

Lencz, Ladislav. 1992. “Úvod." In Etická výchova, by Roberto R. Olivar, 5-10. Bratislava: Orbis Pictus Istropolitana.

Lencz, Ladislav. 1993a. Metódy etickej výchovy. Bratislava: Metodické centrum.

Lencz, Ladislav. 1993b. Pedagogika etickej výchovy. Výchova k prosociálnosti. Bratislava: Metodické centrum.

Lieskovská, Zuzana, et al. 2017. Správa o stave životného prostredia Slovenskej republiky v roku 
2016. Bratislava: Ministerstvo životného prostredia Slovenskej republiky.

Milová, Stanislava, Róbert Medal, and Jana Klocoková. 2012. "Environmentálna výchova a vzdelávanie detí a mládeže - aktuálna situácia na Slovensku.“ Accessed October 16, 2020. http://www.iuventa.sk/ sk/Vyskum-mladeze/Vyskumy-katalog-dat/2012/ Environmentalna-vychova-a-vzdelavanie-detia-mladeze-aktualna-situacia-na-Slovensku.alej.

Olivar, Roche R. 1992. Etická výchova. Bratislava: Orbis Pictus Istropolitana.

Poláková, Eva, and Barbora Bad’urová. 2015. “Anti-bias education and human rights teaching in secondary education of students." In 2nd International Multidisciplinary Scientific Conference on Social Sciences and Arts SGEM2015. Conference Proceedings, book 1, vol. 2, 45-52. https://doi. org/10.5593/SGEMSOCIAL2015/B12/S3.006.

Poláková, Eva. 2016. „Dôležitost’ aplikovaných výskumov pre teóriu i prax etickej výchovy." In Globalizovaná súčasnost', jej morálne a osobnostné výzvy v kontexte etickej výchovy: zborník štúdií $z$ medzinárodnej vedeckej konferencie, edited by Jan Kalisky, 69-74. Banská Bystrica: Belianum.

Poole, Alexandria K. et al. 2013. "A Call for Ethics Literacy in Environmental Education." In Linking Ecology and Ethics for a Changing World. Ecology and Ethics, edited by Ricardo Rozzi, Steward T. A. Pickett, Clare Palmer, Juan J. Armesto, and Baird J. Callicott, vol 1, 347-391. Dordrecht: Springer. SEP. 2009. Štátny vzdelávací program pre 2. stupeň základnej školy Slovenskej republike. Accessed October 12, 2017. http://www.statpedu.sk/sites/ default/files/dokumenty/statny-vzdelavaciprogram/isced2_spu_uprava.pdf.

SEP. 2015. Štátny vzdelávací program pre nižšie stredné vzdelávanie - 2. stupeň základnej školy. Accessed October 9, 2020. https://www.minedu. sk/data/att/7500.pdf.

UNESCO. 2014. Shaping the future we want: UN Decade of Education for Sustainable Development: final report. Paris: UNESCO. 